\title{
Intestinal Adherent Bacteria and Bacterial Translocation in Breast-Fed and Formula-Fed Rats in Relation to Susceptibility to Infection
}

\author{
MAKIKO NAKAYAMA, MASAKO YAJIMA, SEIKO HATANO, TAKAJI YAJIMA, AND \\ TAMOTSU KUWATA
}

Nutritional Food Development Department, Nutrition Science Institute, Meiji Dairies Corporation, 540, Naruda, Odawara, Kanagawa, 250-0862, Japan

\begin{abstract}
The barrier function of the intestinal mucosa is immature in the newborn mammal, and is strengthened by breast milk. We investigated this effect of breast milk by comparing the susceptibility to infection assessed in terms of adherent bacterial colonization of the intestinal tissue (AdC) and bacterial translocation (BT) between breast-fed and formula-fed newborn rats. Threeday-old rat pups were assigned to one of three groups: motherreared (MR), pseudo-cannulated (sham), and artificially reared (AR). AR rats were infused with formula through an intragastric cannula, under the control of a computer-regulated pumping machine. MR and sham rat pups were reared with their respective dams and received breast milk until weaning in a specially designed cage. In 10-d-old rats, there was no significant difference in the fecal or cecal flora between the AR and MR groups, whereas the $\mathrm{AdC}$ and the $\mathrm{BT}$ to the liver were greater in the $\mathrm{AR}$ than MR group. Enterobacteriaceae, Streptococcus and/or Enterococcus, and Staphylococcus were dominantly detected as
\end{abstract}

\section{ABSTRACT}

microorganisms in AdC flora and BT. The AdC flora did not directly reflect the bacterial colonization flora. These findings suggest that AR rat pups mature normally, although there is a greater colonization of Enterobacteriaceae and BT in AR than MR pups. Consequently, the intestinal barrier function of the pups reared by artificial feeding may become susceptible to BT, and AdC may be more indicative than bacterial colonization of the susceptibility to BT. (Pediatr Res 54: 364-371, 2003)
MR, mother-reared
Abbreviations
sham, pseudo-cannulated
AR, artificially reared
BC, bacterial colonization
BT, bacterial translocation
AdC, adherent bacterial colonization
MLN, mesenteric lymph nodes

Recent advances in the quality of infant formulas have increased their similarity to human breast milk. Moreover, there are no major differences in the physical appearance of breast-fed and formula-fed infants. However, breast-fed infants have a lower morbidity and mortality than formula-fed infants. Studies have demonstrated significant infant protection against diarrhea, respiratory tract infections, otitis media, bacteremia, bacterial meningitis, botulism, urinary tract infections, necrotizing enterocolitis, and other diseases while the infant is receiving breast milk (1-5). There is also good evidence of continued protection against these medical conditions for years after breast-feeding has terminated $(1,6-11)$.

We previously reported in a rat study that BT to the liver was greater in formula-fed AR rat pups than in breast-fed rat pups

Received January 22, 2002; accepted November 14, 2002.

Correspondence: Masako Yajima, Ms, Nutrition Science Institute, Meiji Dairies Corporation, 540, Naruda, Odawara, Kanagawa 250-0862, Japan; e-mail: masako_yajima@meiji-milk.com

DOI: 10.1203/01.PDR.0000077482.28990.2D
(12). It was suggested that the outcome is the result of a difference in the intestinal microflora and maturation of the intestinal mucosa.

There are reports on the development of the intestinal microflora in newborn animals, and studies have compared the intestinal microflora of breast-fed and formula-fed newborns. However, few reports have examined the role of the intestinal microflora and adherent bacteria in relation to infectious risks to the newborn during the suckling and weaning periods. In aerobic fecal microflora in human milk-fed and formula-fed infants in the intensive care unit, Staphylococcus was most dominantly detected at greater than $60 \%$ (13). There have been many studies about the pathogenesis of Staphylococcus involving a receptor-mediated-like host-collagen-binding adhesin (14). Stapylococcal aureus collagen adhesion was identified as a virulence determinant in experimental septic arthritis (15). This collagen adhesion was detected in many pathogens such as Escherichia coli O157:H7 (16) and Salmonella (17). From these findings, the bacterial adhesion to the host epithelia would appear to be most important to pathogenic infection. On 
the other hand, secreted IgA plays an important role in intestinal defense mechanisms (18). To clarify the factors influencing these observations, i.e. greater $\mathrm{BT}$ in the $\mathrm{AR}$ group than the MR group, we examined the AdC and IgA concentration in small intestinal tissue washed free of intestinal contents. The risk of BT in newborn formula-fed and breast-fed rats was implied from an assessment of the intestinal adherent microflora and colonization by intestinal microflora.

\section{METHODS}

Our institute's Committee for Research on Experimental Animals approved the experimental protocol. Experiments were conducted in accordance with the National Research Council (NRC) Guide for the Care and Use of Laboratory Animals (NRC, 1985).

Animals. Pregnant time-dated Sprague-Dawley rats were purchased from Japan SLC (Shizuoka, Japan). All animals were housed individually, under controlled temperature (25 \pm $\left.2^{\circ} \mathrm{C}\right)$, humidity $(55 \pm 2 \%$ relative humidity), and light (12-h light-dark cycle). Rats had free access to water and chow (CA-1; Japan Clea, Tokyo, Japan). All deliveries were spontaneous, and $3 \mathrm{~d}$ after birth the rat pups were weighed and randomly assigned to one of three groups: MR, sham, and AR. The pups of the MR group (10 pups) were reared by their mother throughout the study. In the AR group, an intragastric cannula was implanted in 3-d-old pups, and these pups were artificially reared using the method of Kanno et al. (19). In the sham group, intragastric pseudo-cannulation was also performed in 3-d-old pups, but the cannula was not left in place. Each sham-operated rat pup was returned to its mother $3 \mathrm{~h}$ after surgery for rearing until weaning or completion of the study period. These artificial rearing methods were described in our previous study (12), which involved implanting a cannula in the stomach. The milk-pumping side of the cannula tube was passed from inside to outside of the walls of the stomach and abdomen using a guide made of piano wire, and the inner gastric side of the cannula was stopped by a rim with a thin plastic cover to prevent it from being dislodged. Suckling rats begin to nibble on solid food at around $15 \mathrm{~d}$ of age. To prevent this activity, 10-d-old rats and pups in the MR and sham groups were placed in a specially designed cage that denied them access to the food provided for the dams.

Artificial rearing of rats. The milk formula used for the AR rat pups was prepared by the method of Kanno et al. (19) under aseptic conditions, and its composition is shown in Table 1. Kanno et al. (19) prepared a refined formula, the composition of which closely resembled that of rat milk, although the protein components were whey protein isolates and casein from bovine milk. The formula was dispensed into $50-\mathrm{mL}$ sterilized polypropylene bottles, and stored frozen at $-40^{\circ} \mathrm{C}$. The osmotic pressure and $\mathrm{pH}$ of the formula milk were 352 and 6.30 , respectively. The frozen formula was sterilized by gamma ray irradiation ( $30 \mathrm{kGy})$.

The rat pups were given the milk formula by means of intermittent gastric infusion (15-min infusion every $60 \mathrm{~min}$ ), which was controlled by a computer. The volume of formula milk given to the pups was determined daily so as to match the
Table 1. Nutrient composition and physical properties of rat's milk and milk formula

\begin{tabular}{|c|c|c|}
\hline Nutrient (weight/100 mL) & Formula & Rat's milk* \\
\hline Protein $(\mathrm{g})$ & 9.00 & $10.5 \pm 1.5$ \\
\hline Casein & 5.40 & $7.0 \pm 4.8$ \\
\hline Whey & 3.60 & $3.5 \pm 0.5$ \\
\hline Carbohydrate (g) & & $2.0 \pm 1.0$ \\
\hline Lactose & 2.50 & \\
\hline Fat $(\mathrm{g})$ & 12.00 & $11.4 \pm 4.8$ \\
\hline Palm oil & 3.60 & \\
\hline Coconut oil & 3.00 & \\
\hline Soya oil & 2.40 & \\
\hline MCT oil & 1.80 & \\
\hline Corn oil & 1.20 & \\
\hline Cholesterol & 0.04 & \\
\hline \multicolumn{3}{|l|}{ Minerals (mg) } \\
\hline Calcium & 315.00 & $379 \pm 43$ \\
\hline Phosphorus & 207.00 & $222 \pm 21$ \\
\hline Sodium & 128.00 & $196 \pm 44$ \\
\hline Potassium & 122.00 & $83 \pm 19$ \\
\hline Chloride & 160.00 & $140 \pm 16$ \\
\hline Magnesium & 21.00 & $22 \pm 1$ \\
\hline Zinc & 2.40 & ND \\
\hline Copper & 0.0006 & ND \\
\hline Fluorine & 0.07 & ND \\
\hline Iodine & 0.14 & ND \\
\hline \multicolumn{3}{|l|}{ Vitamins (mg) } \\
\hline Cyanocobalamin & 0.00119 & ND \\
\hline Biotin & 0.018 & ND \\
\hline Folic acid & 0.079 & ND \\
\hline Thiamine hydrochloride & 0.881 & ND \\
\hline Pyridoxine hydrochloride & 1.25 & ND \\
\hline Riboflavin sodium phosphate & 1.415 & ND \\
\hline Calcium pantothenic acid & 2.643 & ND \\
\hline$p$-Amino-benzoic acid & 4.404 & ND \\
\hline Nicotinic acid & 4.988 & ND \\
\hline Sodium ascorbate & 47.4 & ND \\
\hline 4-Inositol & 49.725 & ND \\
\hline Choline citrate & 0.14 & ND \\
\hline Vit E: $\alpha$-tocopherol & 2.346 & ND \\
\hline Vit $\mathrm{K}$ & 1.982 & ND \\
\hline Vit A (IU) & 42.8 & ND \\
\hline Vit D (IU) & 10 & ND \\
\hline \multicolumn{3}{|l|}{ Others (mg) } \\
\hline Carnitine & 3.5 & ND \\
\hline Picolinate & 2 & ND \\
\hline Ethanolamine & 3.5 & ND \\
\hline Taurine & 15 & ND \\
\hline Cysteine & 22.5 & ND \\
\hline Serine & 27.5 & ND \\
\hline Tryptophan & 27.5 & ND \\
\hline Energy content $(\mathrm{kJ} / 100 \mathrm{~mL}$ of milk $) \dagger$ & 637 & $632 \pm 235$ \\
\hline Osmolarity $\left(\mathrm{mOsm} / \mathrm{kg} \mathrm{H} \mathrm{H}_{2} \mathrm{O}\right)$ & $343 \pm 12 \ddagger$ & $352 \pm 5$ \\
\hline $\mathrm{pH}$ & $6.5 \pm 0.1 \dagger$ & $6.30 \pm 0.10$ \\
\hline Size of micells $(\mu \mathrm{m})$ & $1.1 \pm 0.1 \dagger$ & $7.8 \pm 0.6$ \\
\hline
\end{tabular}

* Values are mean \pm SD (19).

$\dagger$ Conversion factors: $1 \mathrm{~g}$ protein $=17 \mathrm{~kJ}, 1 \mathrm{~g}$ carbohydrate $=16 \mathrm{~kJ}, 1 \mathrm{~g}$ fat $=37 \mathrm{~kJ}$.

\$ Value obtained by analysis.

Abbreviations used: MCT, medium-chain triglyceride; ND, not determined; Vit, vitamin.

growth observed in pups in the MR group-delivery of formula milk to the respective pup was increased from $1.8 \mathrm{~mL}$ per day at $4 \mathrm{~d}$ of age to $6.6 \mathrm{~mL}$ at $21 \mathrm{~d}$ of age. The syringe on the pump was placed in a refrigerator $\left(5^{\circ} \mathrm{C}\right)$ to prevent bacterial 
growth in the milk formula inside the tubes. Rats were killed if their cannula fell out during artificial rearing.

Microbiologic methods. Each morning, fecal samples were harvested by stroking the anogenital area of each rat with a wet cotton swab. Cecum samples were obtained after organ removal for the BT examination. The cecum samples were immediately placed in preweighed sterile tubes filled with $\mathrm{CO}_{2}$ gas and weighed. The tubes were then placed in an anaerobic chamber, maintained with an atmosphere of $10 \% \mathrm{CO}_{2}, 10 \%$ $\mathrm{H}_{2}$, and $80 \% \mathrm{~N}_{2}$. The specimens were homogenized with prereduced diluent buffer, and, after homogenization, serial 10 -fold dilutions of the homogenates were prepared from each sample. Aliquots $(100 \mu \mathrm{L})$ of each diluent were applied to prereduced BL agar (Eiken, Tokyo, Japan) as a nonselective medium for anaerobes, LBS agar (Becton Dickinson and Company, Cockeysville, MD, U.S.A.) for Lactobacillus and modified NBGT agar for Bacteroides (modified by Yasui et al. (19a)). The plates were incubated anaerobically at $37^{\circ} \mathrm{C}$ for 48 to $72 \mathrm{~h}$. Dilutions were also plated onto TS agar (Becton Dickinson) as a nonselective medium for aerobes, TATAC agar for Enterococcus and Streptococcus, McConkey agar (Eiken) for Enterobacteriaceae, and Staphylococcus medium 110 agar (Eiken) for Staphylococcus. The plates were incubated aerobically at $37^{\circ} \mathrm{C}$ for 24 to $48 \mathrm{~h}$. After incubation, bacteria were identified by observing the shapes of the bacterial colonies and their cellular morphology, Gram staining, and the aerobic and anaerobic growth of the colonies on the BL agar [according to the method reported by Mitsuoka (20)].

The data are reported using common logarithms of bacterial counts per gram of feces or cecum content.

Analysis of BT. The rat pups were anesthetized with ether, and then placed in a bath containing $70 \%$ alcohol. The abdomen of the animal was opened, and the MLNs and liver were harvested for culture of translocated organisms using an aseptic procedure. Each tissue was placed in a sterile preweighed glass homogenizer and weighed. The tissue was homogenized with saline containing $0.2 \%$ peptone. Homogenate samples (100 $\mu \mathrm{L}$ ) were inoculated onto BL agar (Eiken) plates and incubated anaerobically for $72 \mathrm{~h}$ at $37^{\circ} \mathrm{C}$. After incubation, bacteria were identified by observing colony shape and cellular morphology, Gram staining, and aerobic and anaerobic growth. The bacterial counts in the MLNs and the liver were expressed as the mean \pm SD of the log count.

Analysis of intestinal adherent bacteria. The small intestine and colon were harvested for culturing adherent bacteria using an aseptic procedure. Each organ was sliced open and the contents washed three times with $10 \mathrm{~mL}$ of sterile saline containing $0.2 \%$ peptone. Excess moisture remaining after the washes was absorbed with filter paper. Each organ was weighed and homogenized in $0.5 \mathrm{~mL}$ of saline containing $0.2 \%$ peptone with a homogenizer (Asahi Techno Glass Co., Tokyo, Japan) equipped with a glass cylinder (outer diameter $\times$ length: $12 \times 35 \mathrm{~mm}$ ). Subsequently, a 10 -fold serial dilution of homogenates was prepared for each sample, and a sample of the suspension $(100 \mu \mathrm{L})$ was inoculated onto a BL agar plate. After anaerobic incubation for $72 \mathrm{~h}$ at $37^{\circ} \mathrm{C}$, bacteria were identified by observing colony shape and cellular morphology, Gram staining, and aerobic and anaerobic growth.
Analysis of IgA in the small intestine and the plasma. The small intestine was opened along the mesenteric border, and the luminal contents were washed out in the same way as for the analysis of adherent bacteria. The organ was weighed and homogenized in $0.5 \mathrm{~mL}$ of PBS with a homogenizer (Asahi Techno Glass Co.) equipped with a glass cylinder (outer diameter $\times$ length: $12 \times 35 \mathrm{~mm}$ ). The blood was sampled with a syringe from the abdominal aorta. The homogenate and the blood were centrifuged at $3000 \times g$ for $20 \mathrm{~min}$, and the supernatants were frozen at $-40^{\circ} \mathrm{C}$ until used for the measurement of IgA content. Each sample was diluted 2- or 10-fold, and was analyzed with a rat IgA ELISA Quantitation Kit (Bethyl Lab. Inc., Montgomery, TX, U.S.A.).

Statistical analysis. The intestinal bacterial counts of two groups were compared using a $t$ test, and differences among the three groups were compared using a one-way ANOVA and applying Fisher's post hoc test $(p<0.05)$. All statistical analyses were performed using StatView 4.1 (Abacus Concepts, Inc., Berkeley, CA, U.S.A.).

\section{RESULTS}

There were no significant differences in either the body weight or gain in body weight throughout the suckling period and after weaning among the AR, sham, and MR groups.

Fecal flora during the suckling period and after weaning. Figure 1 and Tables 2 and 3 show the development of individual bacterial groups in the feces of MR, sham, and AR rat pups during suckling and after weaning. We showed agedependent changes of bacterial flora in addition to previously reported data [d 10 and d 14 (12)].

As shown in Figure 1A, Enterobacteriaceae was the predominant bacterial group in all feeding groups throughout the suckling period. After weaning, the number of Enterobacteriaceae declined rapidly in the MR and sham groups, whereas in the AR group the number declined more slowly. At d 28, the proportion of Enterobacteriaceae among total viable bacteria was less than $1 \%$ in the MR and sham groups, whereas in the AR group it was $30 \%$ on $\mathrm{d} 28$ and $10 \%$ on $\mathrm{d} 42$.

As shown in Table 2, Clostridium was detected more frequently during late suckling and $1 \mathrm{wk}$ after weaning in the AR group than the MR group. As shown in Table 3, Bacteroides was not detected until d 18 in any of the three groups, and were detected in the feces of both MR and sham rats on $\mathrm{d} 21$, but were not detected until d 25 in the AR group. Moreover, Bacteroides was detected in only $50 \%$ of rat pups in the AR group by $\mathrm{d} 42$.

Cecal and adherent flora in AR, sham, and MR rat pups. Table 4 shows the composition of the cecal flora and the composition of the adherent bacteria in the tissue of the small intestine and colon in both breast-fed and formula-fed 10-d-old rat pups.

The cecal flora did not differ between the AR and MR groups at $10 \mathrm{~d}$, but the numbers of the adherent bacteria of Enterobacteriaceae, Enterococcus and Streptococcus, and total bacteria in the small intestine were significantly larger in the AR group than the MR and sham groups. The numbers of these adherent bacteria in the sham group were values in between 

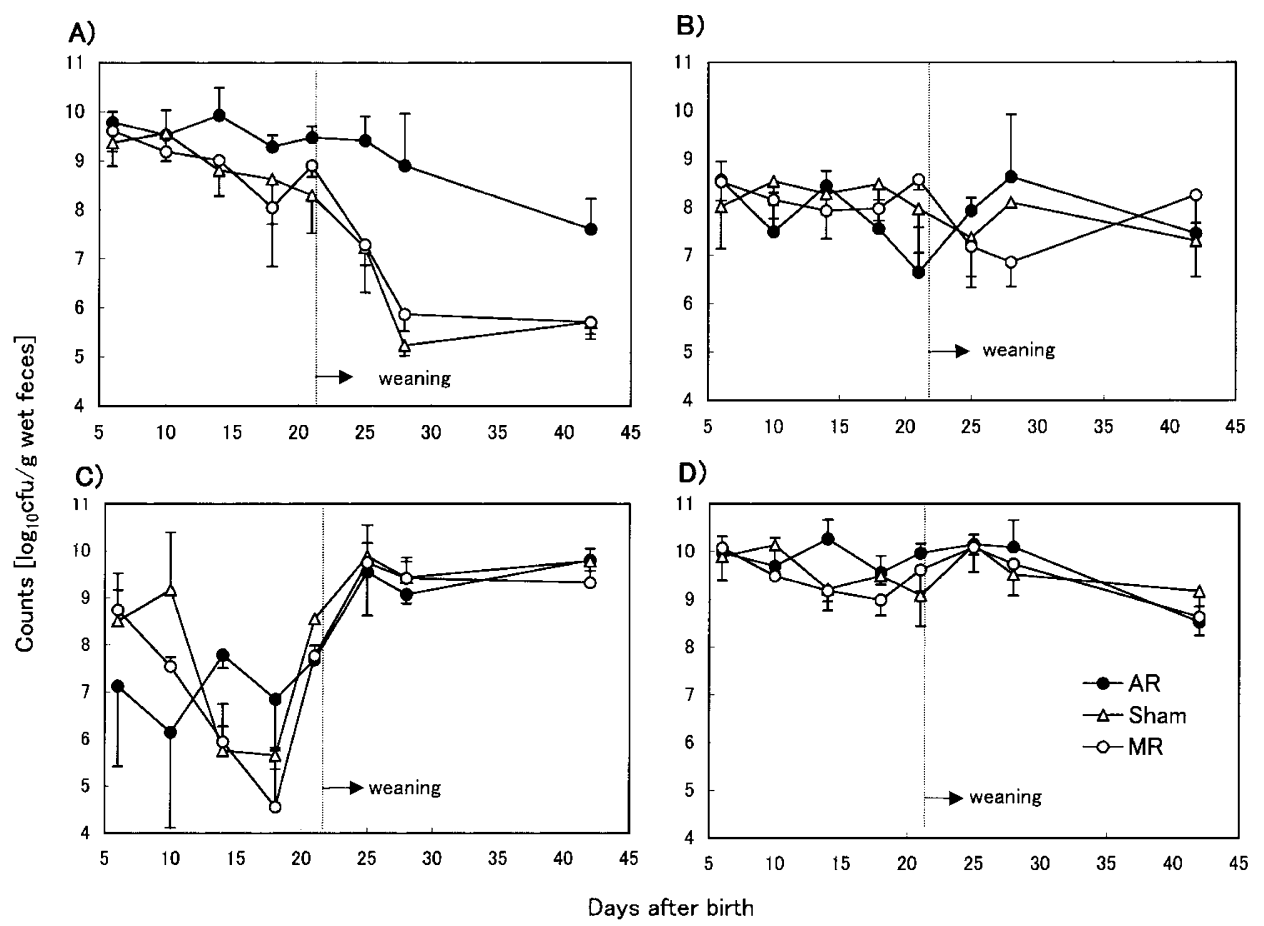

Figure 1. Development of each bacterium in the fecal flora of $\operatorname{AR}(\bullet)$, sham $(\triangle)$, and MR $(0)$ rat pups $(n=3-5)$. Data are the means expressed as $\log _{10}$ colony-forming units per gram of specimen \pm SD (calculated only for positive cultures): Enterobacteriaceae (A), Enterococcus and Streptococcus (B), Lactobacillus $(C)$, total bacteria $(D)$. The data at $10 \mathrm{~d}$ and $14 \mathrm{~d}$ are taken from Yajima et al. (12).

Table 2. The number and frequency of Clostridium in feces of $A R$, sham, and $M R$ rat pups

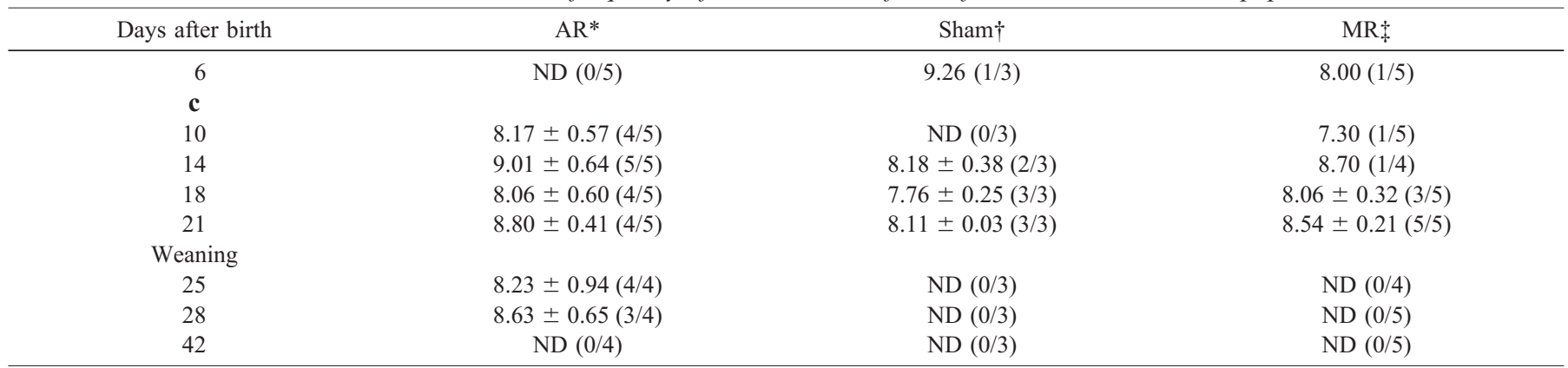

Data are means expressed as $\log _{10}$ colony-forming units per gram of specimen \pm SD (based on positive cultures). Data in parentheses denote number of animals who showed colonization. The data of $10 \mathrm{~d}$ and $14 \mathrm{~d}$ are from Yajima et al. (12).

* Normal breast-fed rat pups.

$\dagger$ Rat pups were cannulated at $3 \mathrm{~d}$ of age, and reared by their mothers after removal of the cannula.

$\$$ Rat pups were cannulated at $3 \mathrm{~d}$ of age, and artificially reared.

Abbreviation used: ND, not detected.

those of the other two groups. In the colon, the adherent bacterial numbers were also values in between those of the others, although they were not significantly different. Adherent Clostridium was only detected in AR rat pups at $10 \mathrm{~d}$.

Bacterial translocation in AR, sham, and MR rat pups. Table 5 shows the incidence and number of BT to the MLNs and liver in 10-d-old MR, sham, and AR rat pups. There was no difference in either value among the three groups. The incidence of BT to the liver was higher in AR rat pups than in either MR or sham rat pups. These results were consistent with our previous data. Viable bacteria in the liver were observed in eight of 17 rat pups in the AR group. No viable bacteria were observed in the 15 rat pups of the MR group, and viable bacteria were only detected in two of 13 rat pups in the sham group.
IgA concentration in the small intestine and in the plasma in AR and MR rat pups. Table 6 shows the total IgA concentration in the small intestinal tissue in AR and MR rat pups aged $14 \mathrm{~d}$. IgA levels were higher in AR pups than in MR pups. The IgA concentration in plasma was also higher but not significantly in AR than in MR pups.

\section{DISCUSSION}

Adherent bacterial counts in the intestine and translocation of bacteria. Few studies have examined intestinal adherent bacteria in vivo. Katayama et al. (21) studied the role of bacterial adherence and the mucous barrier in bacterial translocation in protein-malnourished rats and in endotoxinchallenged rats. They indicated that the adherence of bacteria 
Table 3. The number and frequency of Bacteroides in feces of $A R$, sham, and MR rat pups

\begin{tabular}{|c|c|c|c|}
\hline Days after birth & $\mathrm{AR}$ & Sham & MR \\
\hline 6 & $\mathrm{ND}(0 / 5)$ & $\mathrm{ND}(0 / 3)$ & $\mathrm{ND}(0 / 5)$ \\
\hline 10 & ND $(0 / 5)$ & ND $(0 / 3)$ & $\mathrm{ND}(0 / 5)$ \\
\hline 14 & ND $(0 / 5)$ & ND $(0 / 3)$ & $\mathrm{ND}(0 / 4)$ \\
\hline 21 & ND $(0 / 5)$ & $7.34 \pm 0.86(2 / 3)$ & $7.53 \pm 1.40(4 / 5)$ \\
\hline \multicolumn{4}{|l|}{ Weaning } \\
\hline 25 & ND (0/4) & $9.40 \pm 0.43(3 / 3)$ & $9.51 \pm 0.28(4 / 4)$ \\
\hline
\end{tabular}

Data are mean expressed as $\log _{10}$ colony-forming units per gram of specimen $\pm \mathrm{SD}$ (based on positive cultures). Data in parentheses denote number of animals who showed colonization. The data of $10 \mathrm{~d}$ and $14 \mathrm{~d}$ are from Yajima et al. (12).

Abbreviation used: ND, not detected.

Table 4. The composition of Cecum flora and adherent bacteria in AR, sham, and MR rat pups at $10 \mathrm{~d}$ of age

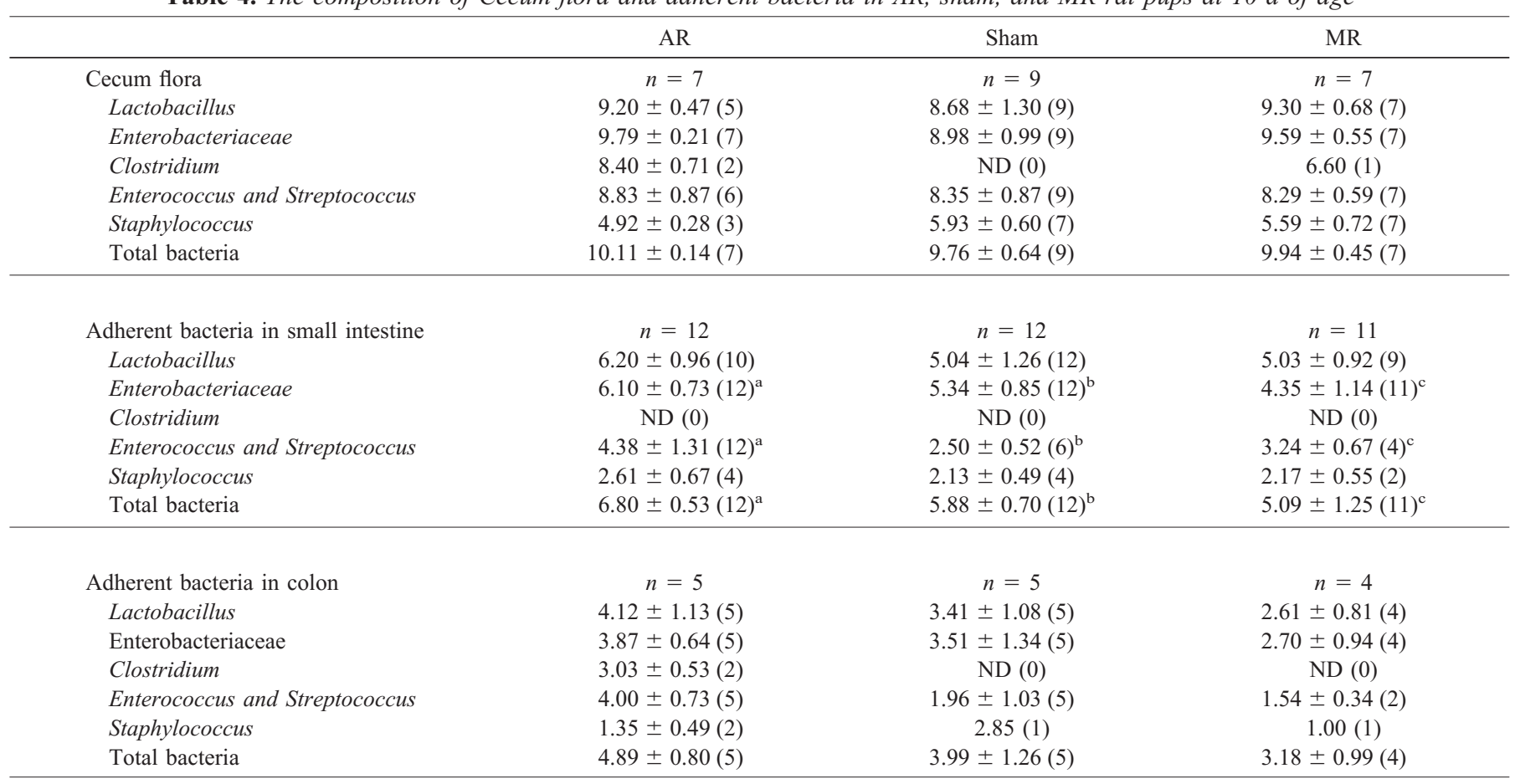

Data are means expressed as $\log _{10}$ colony-forming units per gram of specimen (cecum flora) or per rat (adherent bacteria) \pm SD (based on positive cultures). Data in parentheses denote number of animals who showed colonization.

a,b,c: Different letters donote significant differences $(p<0.05)$ using one-way analysis of variance with Fisher's post hoc test.

Abbreviation used: ND, not detected.

to the intestinal mucosal surface is an important factor in BT, that intestinal mucus modulates bacterial adherence, and that increased levels of mucosal adherent bacteria are associated with a loss of intestinal barrier function to exclude bacteria. In our experiment, the bacterial counts in homogenate samples of the small intestine were significantly more than 10 times higher in the AR group than in the MR and sham groups (Table 4). The species composition of adherent bacteria was not the same as the intestinal flora, and the adherent bacterial count did not directly reflect the intestinal bacterial count. More experiments are needed to elucidate the capability to adhere to mucin or to epithelial cells of each bacterial species, and also to know the mucin levels in experimental groups, to understand how the MR and AR groups differ in mucosal adhesion of bacteria and BT. Antimicrobiologic components such as $\operatorname{IgG}, \operatorname{IgA}$, and lactoferrin are contained in maternal milk. The neonate takes these components from maternal milk, as the neonate itself cannot yet produce them at the same levels as a healthy adult (22). Dickinson et al. (23) elucidated in artificially reared neonatal rabbits that IgA supplementation abrogated BT by enhancing gut mucosal barrier function and that $\operatorname{IgG}$ and lactoferrin had no significant effect. Meanwhile, lactoferrin ameliorated the lipopolysaccharide-induced decrease in the phagocytic effect of neutrophils in neonatal rats and also lowered the higher incidence of BT in AR pups than MR pups (24). Spiekerman et al. (25) elucidated that IgG could cross epithelial barriers by Fc-receptor-mediated transcytosis in adult animals such as humans and mice. The timing of the neonatal gut closure differs between humans and rats, finishing in the late suckling period (17-21 d after birth) in the latter (26). In humans, gut closure has terminated by birth in fullterm infants (27), but in preterm infants, gut closure has not yet 
Table 5. Incidence of bacterial translocation to the MLNs and liver in MR, sham, and AR rat pups at $10 \mathrm{~d}$ of age

\begin{tabular}{|c|c|c|c|c|}
\hline & & AR & Sham & MR \\
\hline \multirow[t]{5}{*}{ MLN } & total & $1.16 \pm 0.59(11 / 17)$ & $1.34 \pm 0.43(7 / 13)$ & $1.28 \pm 0.67(10 / 15)$ \\
\hline & Lactobacillus & $0.30(1 / 17)$ & ND $(0 / 13)$ & $0.30 \pm 0.00(2 / 15)$ \\
\hline & Streptococcus and Enterococcus & $0.82 \pm 0.38(3 / 17)$ & ND $(0 / 13)$ & $\mathrm{ND}(0 / 15)$ \\
\hline & Staphylococcus & $0.92 \pm 0.64(4 / 17)$ & $1.08 \pm 1.10(2 / 13)$ & ND $(0 / 15)$ \\
\hline & Other bacteria & $1.20(1 / 17)$ & $1.00(1 / 13)$ & ND $(0 / 15)$ \\
\hline \multirow{5}{*}{ Liver } & Lactobacillus & ND $(0 / 17)$ & $1.30(1 / 13)$ & ND $(0 / 15)$ \\
\hline & Enterobacteriaceae & $1.55 \pm 0.64(4 / 17)$ & $1.00(1 / 13)$ & ND $(0 / 15)$ \\
\hline & Streptococcus and Enterococcus & $1.00 \pm 0.00(2 / 17)$ & ND $(0 / 13)$ & ND $(0 / 15)$ \\
\hline & Staphylococcus & $1.35 \pm 0.49(2 / 17)$ & ND $(0 / 13)$ & ND $(0 / 15)$ \\
\hline & Other bacteria & ND $(0 / 17)$ & ND $(0 / 13)$ & ND $(0 / 15)$ \\
\hline
\end{tabular}

Data are expressed as $\log _{10}$ colony-forming units (cfu) per gram of tissue \pm SD (based on positive cultures). Numbers in parentheses denote number of rats with $\mathrm{BT} /$ number of total rat.

Abbreviation used: ND, not detected; MLN, $<2$ cfu/rat; Liver, $<10 \mathrm{cfu} / \mathrm{g}$.

Table 6. Amount of IgA in the small intestine, the colon, and the plasma of AR and MR rat pups at $14 d$ of age

\begin{tabular}{|c|c|c|c|c|c|}
\hline & \multicolumn{2}{|c|}{ Small intestine } & \multicolumn{2}{|c|}{ Colon } & $\begin{array}{c}\text { Plasma } \\
(\mu \mathrm{g} / \mathrm{mL})\end{array}$ \\
\hline $\mathrm{AR}$ & $2.0 \pm 1.3$ & $49 \pm 36$ & $5.7 \pm 4.1$ & $34 \pm 26$ & $6.6 \pm 2.9$ \\
\hline
\end{tabular}

Values are mean $\pm \mathrm{SD}$.

$* p<0.05$ compared with AR group, using one-way ANOVA with Fisher's post hoc test.

terminated (28). In regard to the mechanism by which $\operatorname{IgA}$ eliminates intestinal pathogens from breast milk, it was reported that, using transmission electron microscopy and immunofluorescence, aggregates of IgA and Escherichia coli on the mucosal, but not submucosal, surface of the ileal membranes were revealed in vitro in rats (29). We did not examine how much of the IgG or IgA from maternal milk entered the intestine of MR pups, although the IgA concentration of breast milk in one rat was approximately $12 \mathrm{mg} / \mathrm{mL}$ (30). On the other hand, the intestinal mucosal tissue IgA concentration was significantly higher in AR pups than in MR pups at $14 \mathrm{~d}$ of age in our experiment. As shown in Table 6, the average plasma IgA concentration was not significantly higher in the AR than in the MR pups. The plasma IgA concentration of AR pups in our experiment was approximately one third that at $4 \mathrm{wk}$ of age of Sprague-Dawley rats (31). These results would indicate that the mucosal IgA levels in the intestine of AR pups might not be high enough to prevent adhesion or translocation of intestinal bacteria compared with the levels in MR pups given IgA-rich breast milk.

It is interesting that the AR pups might respond to produce more IgA in intestine and systemic blood, too, than MR pups. In histologic examinations of hematoxylin-eosin-stained sections of the duodenum and ileum by light microscopy, the number of interepithelial lymphocytes was significantly (two to three times) higher in AR than MR rat pups at $19 \mathrm{~d}$ after birth (E. Harada, unpublished data), indicating that the mucosal immunity of the AR pups might be strengthened more than that of the MR pups during the suckling period. These findings were not inconsistent with the increased BT and AdC in AR compared with in MR pups. In the small bowel mucosa of human patients in whom BT has been shown to occur, larger numbers of plasma cells and higher IgA and IgM values were presented (32). These findings suggest that BT promotes an increased local immune response.

Köhler et al. (33) recently demonstrated that the IgA concentration in feces was significantly higher in breast-fed than formula-fed infants during the first $3 \mathrm{mo}$, although feces from breast-fed and formula-fed infants inhibited bacterial adhesion on Caco-2 cells to a similar level. They could not examine the bacterial adhesion levels in the intestine of the infants. Further study is needed to describe the relationship between IgA levels in the intestine and the difference of microbial adhesion among the experimental groups.

More BT to the liver was observed in rat pups during the suckling period in the AR group than in the MR group (Table $5)$. This observation is consistent with previous reports (12, 34-38). Also, the bacterial species involved in the translocation did not mirror the composition for the $\mathrm{BC}$ as in our previous report (12). The higher count of adherent bacteria might induce the higher frequency of BT in $10 \mathrm{~d}$. This suggests that the AR group with higher counts of adherent bacteria was exposed to a greater risk of BT than the MR group, indicating that control of adherent bacterial numbers might be important for protection against BT. For that reason, it should be confirmed whether levels of adherent harmful bacteria such as Enterobacteriaceae mirror the increased $\mathrm{BC}$ by harmful bacteria in AR compared with in MR pups after weaning or not.

The adherence of bacteria to the intestinal mucosa has been believed to be an essential and prerequisite step for BC and BT. Sansonetti (39) recently reviewed host-pathogen interactions and highlighted the diversity in the mechanisms of invasion of pathogenic bacteria. In that review, it was described that "[w] hen invasive microorganisms bind to the intestinal epithe- 
lium and disrupt to invade it, recognition of the genetic basis of bacterial pathogenicity involves molecular cross talk established between pathogens and their mammalian target cells." We could not elucidate where the adherent bacteria exist and how they bind to the intestine in our experiments. Using a similar method for the detection of adherent bacteria as ours, Kawasaki et al. (40) showed antiinfectious effects of lactoferrin on the adherent bacterial count. On the other hand, the increased weight of the small intestine of AR compared with that of MR pups was histologically investigated, and the villi and smooth muscle layer was found to be more developed in the AR pups (19). The higher counts of adherent bacteria in AR than in MR pups may partially result from these findings.

Furthermore, the composition of the intestinal adherent bacteria was not similar to that of the translocated bacteria detected in MLNs and the liver (Table 5). Both Enterobacteriaceae and Lactobacillus were frequent adherent bacteria in the small intestine and colon. However, Lactobacillus was detected significantly less often in bacteria translocated to the MLNs and liver in comparison to Enterobacteriaceae. These findings suggest that there are differences in the invasive capability of bacterial species, and also that it is important to control the level of adherent bacteria.

Development of fecal flora in MR and AR rat pups during the suckling and weaning period. Suckling rats begin to nibble on their mother's food at around d, and this dramatically influences the pup's intestinal microflora. To avoid such problems, we used a specially designed cage to control weaning because the MR and sham pups in these cages and the AR pups were weaned at the same time, and were given the same solid food and water - there was no difference in body weight gain after d 21 between the MR and AR groups (data not shown). With the housing set up as above, the transient change in the pattern of fecal microflora, mainly Enterobacteriaceae (Fig. $1 A$ ), and Bacteroides (Table3), during the 3 wk after weaning was quite different between the AR and MR pups.

As shown in Figure 1 and Tables 2 and 3, the transition of fecal microflora in the sham group showed a more similar pattern to that in the MR group than in the AR group after weaning. Consequently, the differences observed between the MR and AR groups seemed to be caused by the formulation of milk (breast milk versus formula) rather than the effect of artificial cannulation. A high incidence and large number of Clostridium in the fecal microflora were observed even after weaning in AR rat pups compared with in MR rat pups (Table 2). But, as shown in Table 3, Bacteroides in the AR group started to appear after $28 \mathrm{~d}$, later than in the MR group, although the counts of Bacteroides in the AR pups were almost the same as those in the MR group. Kleessen et al. (41) examined the influence of two infant formulas and human milk on the development of the fecal flora in newborn infants, and demonstrated that the protein composition of the formula affected the frequency of appearance and bacterial species. The rare appearance of Bacteroides in our experiment may be explained by the composition of the formula. During development, there are species-specific changes in the intestinal microflora (42$44)$. Investigations $(34,42,43)$ have shown that formula-fed infants have larger numbers of intestinal bacteria and greater isolation frequencies for Enterococci, Clostridia, and Enterobacteriaceae in their feces than breast-fed infants. These findings have been confirmed in some of our experiments during the suckling period as reported in our previous paper (12). Even after weaning, Enterobacteriaceae was detected at higher levels in AR pups than in MR pups, although the same chow was fed to all the groups. More experiments would be needed to understand why the Enterobacteriaceae dominate the fecal content of AR pups.

\section{CONCLUSIONS}

In this study, the AR rat pups matured to the same degree as MR pups with respect to physical appearance. However, there were great differences in $\mathrm{BC}, \mathrm{BT}$, and $\mathrm{AdC}$ between the two groups: $\mathrm{BT}$ and $\mathrm{AdC}$ were both higher in the $\mathrm{AR}$ than in the MR group. Higher intestinal adherent bacterial counts were more closely correlated with a more frequent translocation of bacteria at $10 \mathrm{~d}$ in the suckling period. Also, undesirable bacteria like Enterobacteriaceae were more common in the feces of the AR group than of the MR group during the $3 \mathrm{wk}$ after weaning. These differences in the intestinal environment would not normally cause serious problems. However, the weaker intestinal barrier of formula-fed newborns may make them more susceptible than breast-fed newborns to bacterial infection by BT.

Acknowledgments. The authors thank Prof. Emeritus Tomotari Mitsuoka (University of Tokyo) for helpful advice concerning the identification of the intestinal microflora of rats. We also thank Kayo Wake, Keiko Kawanishi, and Minako Hasegawa for technical assistance.

\section{REFERENCES}

1. Hanson LA 1999 Human milk and host defense: immediate and long-term effects Acta Paediatr 88:42-46

2. Victora CG, Smith PG, Vaughan JP, Nobre LC, Lombardi C, Teixeira AM, Fuchs SM, Moreira LB, Gigante LP, Barros FC 1987 Evidence for protection by breastfeeding against infant deaths from infectious diseases in Brazil. Lancet 2:319-322

3. Porro E, Indinnimeo L, Antognoni G, Midulla F, Criscione S 1993 Early wheezing and breast feeding. J Asthma 30:23-28

4. Duncan B, Ey J, Holberg CJ, Wright AL, Martinez FD, Taussig LM 1993 Exclusive breast-feeding for at least 4 months protects against otitis media. Pediatrics 91:867872

5. Pisacane A, Graziano L, Mazzarella G, Scarpellino B, Zona G 1992 Breast-feeding and urinary tact infection. J Pediatr 120:87-89

6. Wilson AC, Forsyth JS, Greene SA, Irvine L, Hau C, Howie PW 1998 Relation of infant diet to childhood health: seven year follow up of cohort of children in Dundee infant feeding study. BMJ 316:21-25

7. Burr ML, Limb ES, Maguire MJ, Amarah L, Eldridge BA, Layzell JC, Merrett TG 1993 Infant feeding, wheezing, and allergy: a prospective study. Arch Dis Child 68:724-728

8. Silfverdal SA, Bodin L, Olcen P 1999 Protective effect of breastfeeding: an ecologic study of Haemophilus influenzae meningitis and breastfeeding in a Swedish population. J Epidemiol 28:152-156

9. Saarinen UM 1982 Prolonged breast feeding as prophylaxis for recurrent otitis media. Acta Paediatr Scand 71:567-571

10. Howie PW, Forsyth JS, Ogston SA, Clark A, Florey CD 1990 Protective effect of breast feeding against infection. BMJ 300:11-16

11. Wright AL, Holberg CJ, Taussig LM, Martinez FD 1995 Relationship of infant feeding to recurrent wheezing at age 6 years. Arch Pediatr Adolesc Med 149:758-763

12. Yajima M, Nakayama M, Hatano S, Yamazaki K, Aoyama Y, Yajima T, Kuwata T 2001 Bacterial translocation in neonatal rats: the relationship between intestinal flora, translocated bacteria, and influence of milk. J Pediatr Gastroenterol Nutr 33:592-601

13. El-Mohandes AE, Keiser JF, Johnson LA, Refat M, Jackson BF 1993 Aerobes isolated in fecal microflora of infants in the intensive care nursery: relationship to human milk use and systemic sepsis. Am J Infect Control 21:231-234 
14. Deivanayagam C, Rich R, Carson M, Owens R, Danthuluri S, Bice T, Hook M, Narayana S 2000 Novel fold and assembly of the repetitive B region of the Staphylococcus aureus collagen-binding surface protein. Structure Fold Des 8:67-78

15. Patti JM, Bremell T, Krajewska-Pietrasik D, Abdelnour A, Tarkowski A, Ryden C, Hook M 1994 The Staphylococcus aureus collagen adhesin is a virulence determinant in experimental septic arthritis. Infect Immun 62:152-161

16. Medina MB 2001 Binding of collagen I to Escherichia coli $\mathrm{O} 157: \mathrm{H} 7$ and inhibition by carrageenans. Int J Food Microbiol 69:199-208

17. Tarkkanen A, Allen B, Westerlund B, Holthofer H, Kuusela P, Risteli L, Clegg S, Korhonenk TK 1990 Type V collagen as the target for type-3 fimbriae, enterobacterial adherence organelles. Mol Microbiol 4:1353-1361

18. Marcotte H, Lavoie MC 1996 No apparent influence of immunoglobulins on indigenous oral and intestinal microbiota of mice. Infect Immun 64:4694-4699

19. Kanno T, Koyanagi N, Katoku Y, Yonekubo A, Yajima T, Kawata T, Kitagawa H, Harada E 1997 Simplified preparation of refined milk formula comparable to rat's milk: influence of the formula on development of the gut and brain in artificially reared rat pups. J Pediatr Gastroenterol Nutr 24:242-252

19a.Yasui H, Yasutake N, Ohwaki M 1979 Immunogenicity of Bacteroides isolated from mice: relationship between immunogenicity and cell wall antigens. Infect Immun $24: 39-46$

20. Mitsuoka T 1992 The human gastrointestinal tract. In: Wood BJB (ed) The Lactic Acid Bacteria. Great Britain at the University Press, Cambridge, pp 69-114

21. Katayama M, Xu D, Specian RD, Deitch EA 1997 Role of bacterial adherence and the mucus barrier on bacterial translocation: effects of protein malnutrition and endotoxin in rats. Ann Surg 225:317-326

22. Goldman AS, Ham Pong A, Goldblum R 1985 Host defenses: development and maternal contributions. Adv Pediatr 32:71-100

23. Dickinson E, Gorga J, Garrett M, Tuncer R, Boyle P, Watkins S, Alber S, Parizhskaya M, Trucco M, Rowe M, Ford H 1998 Immunoglobulin A supplementation abrogates bacterial translocation and preserves the architecture of the intestinal epithelium. Surgery 124:284-290

24. Yajima M, Nakayama M, Yajima T, Kuwata T 1999 High incidence of bacteria translocation to mesenteric lymph nodes and phagocytic activity of neutrophils in suckling rat. FASEB J 13:A591(abstr)

25. Spiekermann G, Finn P, Ward E, Dumont J, Dickinson B, Blumberg R, Lencer W 2002 Receptor-mediated immunoglobulin $\mathrm{G}$ transport across mucosal barriers in adult life: functional expression of FcRn in the mammalian lung. J Exp Med 196:303-310

26. Teichberg S, Isolauri E, Wapnir R, Roberts B, Lifshitz F 1990 Development of the neonatal rat small intestinal barrier to nonspecific macromolecular absorption: effect of early weaning to artificial diets. Pediatr Res 28:31-37

27. Ogra P, Yamanaka T, Kaul N, Fishaut J 1981 Development of mucosal immunity during the perinatal period. In: Lebenthal E (ed) Textbook of Gastroenterology and Nutrition in Infancy. Raven Press, New York, pp 211-217

28. Roberton D, Paganelli R, Dinwiddie R, Levinsky RJ 1982 Milk antigen absorption in the preterm and term neonate. Arch Dis Child 57:369-372
29. Albanese CT, Smith S, Watkins S, Kurkchubasche A, Simmons RL, Rowe MI 1994 Effect of secretory IgA on transepithelial passage of bacteria across the intact ileum in vitro. J Am Coll Surg 179:679-688

30. Elitsur Y, Lee P, Lebenthal E 1987 Immunoglobulins A and G2a in milks of proteinand calorie-restricted dams. J Clin Microbiol 25:2322-2326

31. Kudoh K, Shimizu J, Ishiyama A, Wada M, Takita T, Kanke Y, Innami S 1999 Secretion and excretion of immunoglobulin A to cecum and feces differ with type of indigestible saccharides. J Nutr Sci Vitaminol 45:173-181

32. Woodcock N, Robertson J, Morgan D, Gregg K, Mitchelf C, MacFie J 2001 Bacterial translocation and immunohistochemical measurement of gut immune function. J Clin Pathol 54:619-623

33. Kohler H, Donarski S, Stocks B, Parret A, Edwards C, H S 2002 Antibacterial characteristics in the feces of breast-fed and formula-fed infants during the first year of life. J Pediatr Gastroenterol Nutr 34:188-193

34. Go LL, Ford HR, Watkins SC, Healey PJ, Albanese CT, Donhalek A, Simmons RL, Rowe MI 1994 Quantitative and morphologic analysis of bacterial translocation in neonates. Arch Surg 129:1184-1190

35. Go LL, Albanese CT, Watkins SC, Simmons RL, Rowe MI 1994 Breast milk protects the neonate from bacterial translocation. J Pediatr Surg 29:1059-1064

36. Arvola T, Rantala I, Marttinen A, Isolauri E 1992 Early dietary antigens delay the development of gut mucosal barrier in preweaning rats. Pediatr Res 32:302-305

37. Steinwender G, Schimpl G, Sixl B, Kerbler S, Ratschek M, Kilzer S, Hollwarth ME, Wenzl HH 1996 Effect of early nutritional deprivation and diet on translocation of bacteria from the gastrointestinal tract in the newborn rat. Pediatr Res 39:415-420

38. Udall JN, Colony P, Fritze L, Pang K, Trier JS, Walker WA 1981 Development of gastrointestinal mucosal barrier. II. The effect of natural versus artificial feeding on intestinal permeability to macromolecules. Pediatr Res 15:245-249

39. Sansonetti P 2002 Host-pathogen interactions: the seduction of molecular cross talk Gut 50:III2-8

40. Kawasaki Y, Tazume S, Shimizu K, Matsuzawa H, Dosako S, Isoda H, Tsukiji M, Fujimura R, Muranaka Y, Ishida H 2000 Inhibitory effects of bovine lactoferrin on the adherence of enterotoxigenic Escherichia coli to host cells. Biosci Biotechnol Biochem $64: 348-354$

41. Kleessen B, Bunke H, Tovar K, Noack J, Sawatzki G 1995 Influence of two infant formulas and human milk on the development of the faecal flora in newborn infant. Acta Paediatr 84:1347-1356

42. Orrhage K, Nord CE 1999 Factors controlling the bacterial colonization of the intestine in breastfed infants. Acta Paediatr Suppl 430:47-57

43. Yoshioka H, Fujita K, Sakata H, Murano K, Iseki K 1991 Development of the norma intestinal flora and its clinical significance in infant and children. Bifidobact Microfl 10:11-17

44. Smith HW 1965 The development of the flora of alimentary tract in young animals J Pathol Bacteriol 90:495-513 